Vol 41 (2016) No 184 383-398

\title{
The Impact of Organizational Justice on the Quality of the Leader- Member Relationship in Public versus Foundation Universities
}

\author{
Nisan Selekler-Goksen ${ }^{1}$, Özlem Yildirim-Öktem ${ }^{2}$, Kıvanç Inelmen ${ }^{3}$
}

\begin{abstract}
This study investigates the impact of organizational justice on the quality of leader-member exchange relationships in the Turkish higher education context. Public and foundation universities are compared, as extant literature reveals significant differences between them. The study employs a sequential mixed-method design. Surveys from 182 academicians from faculties of economics and administrative sciences in Istanbul are collected through key contact persons or via e-mails. Surveys are complemented by 17 face-to-face semi-structured interviews, most of which were conducted at the interviewees' universities. Findings point to a strong impact of informational justice that is modestly complemented by procedural justice on the quality of the leader-member relationship in public universities. In foundation universities, however, procedural, informational and interpersonal justice dimensions influence the quality of the leader-member relationship in a balanced manner. The study also has implications for university administrators.
\end{abstract}

Keywords

Organizational justice Leader-member exchange relationship

Higher education Foundation university

Public university

Mixed-method design

Article Info

Received: 27.11.2015

Accepted: 03.04.2016

Online Published: 27.04.2016

DOI: 10.15390/EB.2016.6139

\section{Introduction}

Mozart's famous opera Don Giovanni starts with an aria where Leporello complains of his lot: "Night and day slaving away, For someone who is never satisfied, ... I want to be a gentleman, And I don't want to be a servant anymore ..." This cry is echoed by many employees today, whose need for respect, appreciation, and fairness is not less than what it was in Leporello's era. Indeed, research in many diverse contexts confirms that employee perceptions of how fairly they are treated influence the quality of their relationship with the supervisor (Tekleab, Takeuchi, \& Taylor, 2005), which in turn has positive outcomes for supervisors, subordinates, work units, and the organization in general (Colquitt et al., 2013; Graen \& Uhl-Bien, 1995).

This study aims to identify the impact of organizational justice on the quality of leadermember exchange (LMX) relationships in the higher education context. University education is a vital tool for dealing with changing labor market demands in knowledge-based economies (Sam \& van der Sijde, 2014). In recent decades, higher education has witnessed many significant changes, such as rapidly increasing demand, decreasing availability of financial support from governments,

\footnotetext{
${ }^{1}$ Boğaziçi University, School of Applied Disciplines, Department of International Trade, Turkey, goksenn@boun.edu.tr

2 Boğaziçi University, School of Applied Disciplines, Department of International Trade, Turkey, ozlem.yildirim1@boun.edu.tr

${ }^{3}$ Boğaziçi University, School of Applied Disciplines, Department of Tourism Administration, Turkey, inelmenk@boun.edu.tr
} 
proliferation of private universities, development of cross-border academic programs and increased mobility of students and academics (Dill, 2003; Erdem, 2012; Mathooko \& Ogutu, 2015). All these changes led to an intense competition among universities for successful academics, students, financial support, and research funds (Dill, 2003). Attracting and maintaining a strong faculty is a key success factor for universities because it is the academic staff that defines a university, provides legitimacy for the credentials a university confers, and helps secure research funds (Mathooko \& Ogutu, 2015).

In the last few decades, the number of universities, particularly foundation universities ${ }^{1}$, has increased dramatically in Turkey (Gunay \& Gunay, 2011). Demand for faculty members has shown a similar increase and a gap has emerged between the demand for and supply of academics (Cetinsaya, 2014). There have been numerous transfers of academics from state universities to foundation universities as well as among foundation universities (Barblan, Erguder, \& Guruz, 2008). Therefore, attracting and retaining highly qualified and motivated academics has become a vital issue for universities in Turkey.

This study has three major contributions. First, it adopts a comparative approach and differentiates between public and foundation universities; extant literature reveals differences between them in terms of their culture, structure, and processes (Ferreira \& Hill, 2008) as well as performance and job satisfaction of the faculty (Bas \& Ardic, 2002; Munaf, 2009). Second, the study employs a mixed-method design, combining survey results with information collected through interviews. Semi-structured interviews conducted in the interviewees' work settings enabled an understanding of the academics' accounts of their own university's social contexts, interactions with their supervisors and perceptions of processes (Iloh \& Tierney, 2014). This helped to broaden and deepen the understanding of the relationship between organizational justice and LMX quality. Finally, the study contributes to the scant literature on organizational justice and its outcomes in the context of universities in Turkey (Kutanis \& Cetinel, 2009). These contributions may also provide implications for higher education administrators.

The next two sections introduce the theoretical framework of the study and put forward hypotheses based on the literature review. These are followed by a section on the research context. The subsequent three sections discuss the methods, present the findings, and provide a discussion of findings and implications of the study. The paper concludes with the limitations of the study and suggestions for future research.

\section{Theoretical Framework}

Social exchange theory (SET) is considered one of the most influential approaches to understanding behavior in organizations (Cropanzano \& Mitchell, 2005). The theory views organizations as arenas for transactions which can be economic or social in nature (Camerman, Cropanzano, \& Vandenberghe, 2007; Cropanzano, Prehar, \& Chen, 2002). Economic exchanges are short-term oriented in nature, and are based on explicit duties and obligations, with little emotional attachment. Social exchanges, on the other hand, are more long-term oriented, involve the transaction of more abstract goods, and are characterized by emotional attachments, loyalty, trust and mutual commitment (Camerman et al., 2007; Cropanzano \& Rupp, 2008).

An exchange relationship is often initiated by the more powerful party such as a supervisor in an organizational context. When a supervisor provides something of value to employees, it causes them to feel obligated to reciprocate the favorable treatment in the future through their attitudes and behaviors (Cropanzano \& Rupp, 2008). Such satisfactory interactions between leaders and their members lead to the development of a high quality relationship between them (Erdogan \& Liden, 2006). Leader-member exchange refers to this dyadic relationship that develops through a series of exchanges between a supervisor and an employee over time (Bauer \& Green, 1996). Trust,

${ }^{1}$ Foundation universities in Turkey are privately funded higher education institutions. They are sometimes also called "private universities", but they are not permitted to make profit by Turkish Higher Education Law. 
organizational commitment and justice are commonly recognized antecedents of LMX quality (Erdogan, Liden and Kramer, 2006; Masterson, Lewis, Goldman, \& Taylor, 2000).

The relationship between justice and LMX has been widely studied from a SET perspective (Chernyak-Hai \& Tziner, 2014; Masterson et al., 2000; Tekleab et al., 2005). Organizational justice refers to employees' perception of how fairly they are treated. On the basis of SET, justice is a symbolic contribution made by the supervisor and perceived as valuable by the employee (Colquitt et al., 2013; Masterson \& Lensges, 2015). When employees perceive that they are treated justly, this creates a favorable attitude and motivates them to reciprocate in the future. This, in turn, enhances the quality of the relationship between the leader and the member.

\section{Literature Background and Hypotheses Development}

\section{Leader-Member Exchange}

Leader-member exchange relationship refers to the dyadic relationship that develops between a supervisor and a subordinate over time and reflects the degree to which this exchange is characterized by mutual trust, respect, and loyalty (Brower, Schoorman, \& Tan, 2000; Graen \& UhlBien, 1995; Liden, Sparrowe, \& Wayne, 1997). Supervisors do not behave in the same way toward all their subordinates; each dyadic relationship evolves differently and is unique. Thus, a supervisor with ten subordinates may have up to ten different kinds of interactions with these subordinates (Bauer \& Green, 1996). Supervisors may use their power and organizational resources to develop different social exchange relationships with their subordinates.

Group members who enjoy high quality relationships with the leader are designated as ingroup members. They enjoy preferential treatment and tend to have more interesting and desirable tasks, increased responsibility, greater status, information sharing, career development opportunities, tangible rewards, and personal support and approval (Biron \& Boon, 2013). From a social exchange theory perspective, they reciprocate by displaying more loyalty, commitment and trust than the others. Those with a low quality relationship with the leader are described as out-group members. The leader's relationship with out-group members is more likely to be shaped by contractual duties and formal job descriptions. This, in turn, may decrease loyalty, trust and enthusiasm for work on the part of the employee (Biron \& Boon, 2013). Additionally, the employee becomes more responsive to the economic rather than the social exchange side of the work relationship (Bolat, 2010; Walumbwa, Cropanzano, \& Hartnell, 2009).

\section{Organizational Justice}

Organizational justice refers to employees' perceptions of whether they are treated fairly or not. It has become a popular research topic for many scholars aiming to understand behavior in an increasingly diverse work environment (Cohen-Charash \& Spector, 2001; Colquitt et al., 2013). Organizations are keen to portray an image of attributing importance to fairness because it helps employees feel they are respected members of the company, and brings about positive behaviors in the organization. An unfair atmosphere, on the other hand, is likely to trigger improper actions as well as deviant behavior and thus affects organizational goal attainment negatively (Beugre, 2002; Folger \& Bies, 1989). There is a general consensus on the multidimensional nature of the organizational justice construct. It is often regarded as consisting of distributive, procedural, informational and interpersonal dimensions (Colquitt, 2001), and if all these attributes are balanced in an organization, high quality relationships can be expected among employees (Tekleab et al., 2005).

Distributive justice refers to fairness in the allocation of tangible or/and intangible rewards. This dimension is based mainly on the equity perspective; employee perceptions of fairness are based on comparisons they make between their own and others' input-outcome ratios (Cohen-Charash \& Spector, 2001). Distributive justice dimension is based more on economic than on social exchange (Erdogan et al., 2006). On the basis of SET, distributive justice is an input to the leader-member relationship, so it can be expected to improve LMX quality. 
In academia, the immediate supervisor's impact on the distribution of outcomes is quite limited, especially in public universities. Promotion criteria are determined by the state and/or the university, research budgets are allocated on the basis of project quality, and in the research context, salaries in public universities are determined by the government. In foundation universities, on the other hand, boards of trustees have the last say on a wider spectrum of decisions. However, the immediate supervisor has the most comprehensive information about the teaching and research activities of the academicians and may have an indirect impact on their outcomes. For example, a heavy course load and high expectations in terms of service to the department may decrease research productivity and therefore delay promotions. Additionally, in the context of foundation universities, the supervisor may act as a bridge between the academic and the university administration, that is, the rectorate and the board of trustees, who have the final say about the distribution of outcomes. Due to this additional role that supervisors may play in foundation universities, distributive justice can be hypothesized to be a significant antecedent of LMX in foundation universities.

H1: Distributive justice will be an antecedent of academics' LMX in foundation universities, but not in public universities.

Procedural justice refers to the perceived fairness of decision-making processes and the degree to which they are consistent, accurate, unbiased, and open to voice and input (Colquitt et al., 2013). The fairness of the process through which a decision is made is as important as how fair the outcomes are. When decisions are made using unbiased criteria in a consistent manner, and when subordinates are able to voice concerns, employees are likely to have positive perceptions of procedural justice. It is the manager's responsibility to achieve procedural justice in the minds of the employees (Folger \& Bies, 1989); procedural justice is therefore closely linked to the relationship with the manager (Lee, Gillespie, Mann, \& Wearing, 2010). When individuals perceive injustice, they try to identify the party accountable for the injustice and direct their reactions to that party (Masterson et al., 2000). Thus, if employees attribute procedural injustice to other parties-because these other parties obviously set the rules of the game - they may detach the leader from such perceptions of unjust behavior.

Public universities in Turkey are state institutions and are governed in line with relevant legislation. They enjoy very little autonomy in shaping the rules, regulations and procedures governing them (Akbulut, Seggie, \& Borkan, 2015; Mizikaci, 2006). However, the supervisor may still have a role in the formation of perceptions of procedural justice by implementing procedures consistently and objectively, and by providing voice to the subordinates. Foundation universities, on the other hand, are relatively more autonomous in that they are free to establish their own administrative structures (Mizikaci, 2006; YÖK, 2007). Additionally, because foundation universities are not fully institutionalized (YÖK, 2007), the immediate supervisor is more likely to have a say in shaping the procedures and their implementation. In foundation universities, procedural justice may be a stronger determinant of LMX than in public universities because in the latter, unjust behavior may also be attributed to the Higher Education Council due to that institution's impact on rules, regulations and procedures. Therefore, the following hypothesis is put forward:

H2: Procedural justice will be an antecedent of academics' LMX in foundation universities, but not in public universities.

Interactional justice pertains to the interpersonal side of organizational practices and refers to the perceived fairness of the enactment or implementation of procedures (Colquitt et al., 2013; Colquitt, 2001). Among the dimensions of justice, interactional justice is considered a particularly efficacious predictor of reactions to the supervisor and the immediate work environment, as it focuses on the one-to-one interaction between the supervisor and the employee and fosters trust between them (Cropanzano, Bowen, \& Gilliland, 2007; Cropanzano et al., 2002). Thus, there is a tendency in the literature to give the lead role to interactional justice as an antecedent of LMX (e.g. Burton, Sablynski, \& Sekiguchi, 2008; Masterson et al., 2000). Interactional justice has two sub-dimensions: interpersonal and informational justice. 
Interpersonal justice indicates how employees are treated within the framework of respect and dignity by the authorities in charge of allocating outcomes in an organization (Colquitt, 2001). In a comparative study that included Turkey, employees' definition of justice was found to emphasize respect, appreciation and equal treatment, all of which are indicators of interpersonal justice (MinibasPoussard \& Erkmen, 2008). It was also shown that, among people's daily experiences of injustice, those concerned with the manner of interpersonal treatment constituted the most important category (Loi, Yang, \& Diefendorff, 2009). Being so pervasive, interpersonal justice is hypothesized to be a significant determinant of LMX in both types of universities.

H3: Interpersonal justice will be an antecedent of academics' LMX in both public and foundation universities.

The second sub-dimension of interactional justice is informational justice, and it relates to the adequacy of the explanations given in terms of their timeliness, specificity, and truthfulness with no neglect of the employees' concerns (Cropanzano et al., 2007). High levels of informational justice can reduce secrecy and perceived dishonesty and foster trustworthiness (Loi et al., 2009). Informational justice can be expected to be a significant determinant of LMX quality in both public and foundation universities, as trust is the key to a high quality relationship between a supervisor and an employee. Particularly in public universities, where the supervisor has more limited control over the distribution of outcomes and procedures through which they are distributed, the quality of LMX is expected to depend primarily on informational justice. Timely, comprehensive, and truthful information about the outcomes and the rules, regulations, and procedures followed to reach them may decrease the level of uncertainty felt by employees and facilitate their ability to follow the necessary processes to reach outcomes. Therefore, the following hypothesis is put forward:

H4: Informational justice will be an antecedent of academics' LMX in both types of universities but will be particularly important in public universities.

Research Context

When the first foundation university was established in 1984, there were 27 public universities in Turkey. As of 2015 there were 109 public and 76 foundation universities (yok.gov.tr). While the number of public universities has more than doubled in the last decade, that of foundation universities has more than tripled. This tremendous increase in the number of higher education institutions makes attracting and retaining high quality academics a major problem (Cetinsaya, 2014).

Turkey's higher education model carries many characteristics of a state-centered model in which the state directly coordinates most aspects of higher education (Dobbins, Knill, \& Vögtle, 2011). In both public and foundation universities in Turkey, the state plays a crucial role. It determines enrollment numbers, administers the examinations for university admissions, approves the opening and closing of departments and programs, and shapes academic governance structures by requiring the establishment of administrative bodies such as the university senate or faculty boards. This centralized character of Higher Education Council influences several managerial functions in universities, such as planning and regulating, selecting, and organizing (Akbulut et al., 2015).

In public universities, however, the state plays an even more significant role. Finances are allocated by the state in an itemized fashion, salaries are determined by the Ministry of Finance, and Ministry approval is required for employing a new academic staff member or promoting one. Moreover, appointments of rectors and deans are regulated by the Higher Education Council. In foundation universities, on the other hand, boards of trustees assume an increasingly more significant role (De Boer \& File, 2009). They are responsible for preparing the university's budget, appointing the rector and the deans, hiring academics, and determining salaries (YÖK, 2007). Thus, foundation universities enjoy more autonomy from the state compared to public universities. Additionally, according to the Higher Education Council (YÖK, 2007), most foundation universities are not yet institutionalized. 


\section{Method}

\section{Sample and the Procedure}

In this study, a sequential mixed-method design (Creswell \& Plano-Clark, 2007) was employed to broaden and deepen the understanding about a relatively abstract topic, namely, the impact of justice dimensions on leader-member relationships. This was achieved by complementing the results from questionnaires with data obtained in interviews with academics. When the target population was determined, there were nine public and 32 foundation universities in Istanbul. This accounted for half of foundation and 30 percent of all universities in Turkey. In addition to hosting the first higher education institutions, universities in Istanbul have often been taken as role models by newer ones in other cities (Usdiken, 2004). Therefore, the case of Istanbul deserves special attention.

In order to achieve a level of uniformity, full-time academics of only faculties of economics and administrative science were included in this study. This faculty was chosen as it commonly exists in vast majority of universities. Only five universities did not have faculties of economics and administrative sciences and thus were eliminated from the population. Eleven universities were still hiring academicians, had not yet completed their formation stages and had no graduates as of 2012, so these were also eliminated from the sample. The target population thus includes academics of six public and 19 foundation universities.

For the quantitative phase of the study, 1168 full-time faculty were approached through key contact persons or via e-mail and invited to complete a questionnaire, 182 of which were used in the analysis after the elimination of incomplete questionnaires and ones that had missing responses on the dependent variable. Additionally, a raw data screening was conducted for the necessary linearity check, resulting in a public university sample of 98 and a foundation university sample of 84 academics. This corresponds to a response rate of $15.60 \%$.

In the qualitative phase, 17 semi-structured in-depth interviews were conducted over the course of a year. Judgmental sampling was used; in selecting interviewees, a balance was assured between public and foundation universities, males and females, and academic titles. There were seven female and ten male interviewees from seven public and eight foundation universities. Three of the interviewees were professors, six were associate professors, six were assistant professors, and three were instructors. Eleven of the interviewees had received their $\mathrm{PhD}$ from a Turkish university, while the remaining six had earned their degrees from a university in either the USA or Europe. The tenure of the interviewees in their respective universities ranged from three to 24 years, with an average of 11.29. All but three interviews were conducted at the university where the academics were employed. With the exception of one case where the interviewee did not give consent, interviews were recorded and later verbatim transcribed, allowing the interview to proceed unimpaired by note-taking, but with all information available. Interviews, on average, lasted 40.6 minutes.

\section{Measures}

In the questionnaire, the LMX7 scale as used by Tekleab and Taylor (2003) is employed and consists of seven items. For the measurement of organizational justice perceptions, the scale developed by Colquitt (2001) is used. The scale includes four items for distributive justice, seven items for procedural justice, four items for interpersonal justice, and five items for informational justice. Response options for all scales are delivered on a Likert scale where possible responses range from 1 (strongly disagree) to 5 (strongly agree), with higher scores indicating a higher level of the measured variable. The reliability and face validity of the scales in Turkish were evaluated with a pilot study of 25 academics with various titles from various disciplines and different cities in Turkey. All Cronbach's Alphas were higher than 0.85 . Thus, the psychometric properties of the scales were found fit for the main study. In response to feedback received from the participants of the pilot study, clarifications were made in the wording of the questions to improve understandability. 
In the main study, the Cronbach's Alpha scores ranged between 0.84 and 0.95 and thus the internal reliability of the scales was deemed satisfactory (see Tables 1 and 2). Factor analysis provided a five-component matrix where all five scales used in the study were loaded in a theoretically meaningful manner, providing evidence for construct validity of the questionnaire $(\mathrm{KMO}=0.934$, Bartlett's test $=4575.518, \mathrm{p}<0.001)$. These scales were previously adapted to the Turkish context by Inelmen, Ozgumus, Parlak, Salti, \& Sariot, (2010) and a similar factor structure was obtained by them. The questionnaire used in the present study can be found in Appendix 1.

The semi-structured interview protocol included questions which probed academics' general conceptions of justice (e.g. "How would you define just/unjust treatment of an academic in the context of a university?"), their perceptions of how fairly they are treated along the four dimensions of justice (e.g. "Considering the procedures and their implementation in your university, how do they influence your perception of justice?"), and their relationships with their supervisors ("How would you describe your relationship with your immediate supervisor?"). These main themes were developed on the basis of the relevant literature as well as the quantitative findings of the study. The verbatim transcriptions were read by each author and categorized under pre-defined themes by mutual agreement.

\section{Findings}

A comparison of the faculty in public and foundation universities (Tables 1 and 2) reveals that faculty in foundation universities report a higher quality of LMX ( $t=-2.06)$ and have more positive perceptions of distributive $(\mathrm{t}=-2.00)$, interpersonal $(\mathrm{t}=-3.04)$ and informational justice $(\mathrm{t}=-2.47)(\mathrm{p}<.05)$. They also report a slightly higher degree of procedural justice, but the difference is not statistically significant ( $\mathrm{t}=-0.99 ; \mathrm{p}>.05)$. Additionally, both groups are most satisfied with procedural justice and least satisfied with distributive justice dimensions. For both types of university, correlation analyses reveal that all the dimensions of justice are positively and significantly correlated with LMX. While distributive justice has the lowest correlation with LMX, informational justice dimension has the highest. There is also a high correlation between interpersonal and informational justice. However, according to Colquitt (2001), these are two distinct constructs referring to different aspects of communication, as also used in the present study.

Table 1. Descriptives and Correlation Analyses for Academics in Public Universities

\begin{tabular}{lcccccc}
\hline & Mean (S.D.) & $\mathbf{1}$ & $\mathbf{2}$ & $\mathbf{3}$ & $\mathbf{4}$ & $\mathbf{5}$ \\
\hline 1. Distributive Justice & $12.28(3.97)$ & $(.92)$ & & & & \\
2. Procedural Justice & $19.59(6.83)$ & $.517^{*}$ & $(.90)$ & & & \\
3. Interpersonal Justice & $15.94(3.40)$ & $.436^{*}$ & $.692^{*}$ & $(.94)$ & & \\
4. Informational Justice & $16.80(5.15)$ & $.457^{*}$ & $.662^{*}$ & $.748^{*}$ & $(.94)$ & \\
5. LMX & $21.57(5.50)$ & $.340^{*}$ & $.611^{*}$ & $.594^{*}$ & $.798^{*}$ & $(.84)$ \\
\hline Note: ${ }^{*}$ Correlations significant at 01 level. Figures in the & & & & & &
\end{tabular}

Note: *Correlations significant at .01 level. Figures in the diagonal are Alpha reliabilities.

Table 2. Descriptives and Correlation Analyses for Academics in Foundation Universities

\begin{tabular}{lcccccc}
\hline & Mean (S.D.) & $\mathbf{1}$ & $\mathbf{2}$ & $\mathbf{3}$ & $\mathbf{4}$ & $\mathbf{5}$ \\
\hline 1. Distributive Justice & $13.35(3.25)$ & $(.87)$ & & & & \\
2. Procedural Justice & $20.58(6.56)$ & $.633^{*}$ & $(.92)$ & & & \\
3. Interpersonal Justice & $17.51(3.57)$ & $.511^{*}$ & $.478^{*}$ & $(.95)$ & & \\
4. Informational Justice & $18.73(5.39)$ & $.476^{*}$ & $.666^{*}$ & $.771^{*}$ & $(.94)$ & \\
5. LMX & $23.21(5.18)$ & $.479^{*}$ & $.637^{*}$ & $.682^{*}$ & $.773^{*}$ & $(.90)$ \\
\hline
\end{tabular}

Note: ${ }^{*}$ Correlations significant at .01 level. Figures in the diagonal are Alpha reliabilities. 
Results of the regression analyses show that distributive justice is not a statistically significant antecedent of LMX for academics in both types of university (Table 3). Because distributive justice was expected to be a significant antecedent of LMX in foundation universities but not in public universities, Hypothesis 1 is partially supported. Interviews with academics from foundation universities revealed that the distribution of rewards is centralized in the hands of the board of trustees. An interviewee from a foundation university (FOU) said:

"It is the head of the board of trustees that approves the number of days for which we can be absent for a conference and decides whether we will be reimbursed for your expenditures. Even after the university's academic councils have given approval, everything may be cancelled by the head of the board of trustees. This happened to me and my friends before." (Assist. Prof., FOU)

Because supervisors are not involved in the distribution of rewards, academics' perception of distributive justice does not influence the quality of their relationship with their supervisors. Thus, they do not seem to direct their reactions towards a party whom they do not hold responsible for unjust behavior.

In line with the expectations put forward in Hypothesis 1, an interviewee from a public university (PU) declared:

"There are problems in terms of the distribution of workload, but I think this is a systemic problem emerging from the nature of state universities. If the department chairperson is replaced, not much would change." (Assoc. Prof., PU)

Table 3. The Regression Models for Academics in the Two Types of Universities

\begin{tabular}{lll}
\hline Academics & in Foundation Universities $(\mathbf{n}=\mathbf{8 4})$ & in Public Universities $(\mathbf{n}=\mathbf{9 8})$ \\
\hline Gender & -.049 & -.022 \\
Administrative duty & .024 & -.081 \\
Academic Title & .124 & .100 \\
Distributive Justice & -.046 & -.034 \\
Procedural Justice & $.353^{* *}$ & $.224^{*}$ \\
Interpersonal Justice & $.270^{*}$ & -.074 \\
Informational Justice & $.351^{* *}$ & $.741^{* * *}$ \\
Adj. $\mathbf{R}^{2}$ & $.613^{* * *}$ & $.648^{* * *}$ \\
\hline
\end{tabular}

Note: All regression coefficients are standardized. The marked figures were statistically significant at $\left.{ }^{*}\right) 0.05,\left(^{* *}\right)$ 0.01 and ${ }^{(* *)} 0.001$ levels. Gender (dummy variable: $0=$ Female, $1=$ Male). Administrative duty (dummy variable: $0=$ None, $1=$ At least one $)$. Academic tittle $(1=$ professor, $2=$ associate professor, $3=$ assistant professor, $4=$ fulltime instructor). Durbin-Watson test scores were 2.09 and 2.33, respectively. VIFs ranged between 1.00 and 3.58 for all variables that were included to the regressions.

In Hypothesis 2, procedural justice was expected to be an antecedent of LMX only for academics of foundation universities. However, regression analyses reveal that it significantly influences LMX in both types of university. Therefore, Hypothesis 2 is also partially supported.

Although public universities are more institutionalized, interviews show that the implementation of these rules and procedures is often relationship-based. For example, an interviewee complained:

"You would expect rules to be obeyed but it is not so; it is relational. Everybody is equally unjustly treated, but of course, relational capital matters." (Assist. Prof., PU) 
Additionally, having voice in decision-making is a highly important element of the formation of perceptions of procedural justice. This may be another reason why procedural justice is an antecedent of LMX in public universities. Several academics referred to this point in their interview:

"When a practice or a procedure is going to be changed, we work on it as a department. It gives me the feeling that my opinions and experience count." (Assoc. Prof., PU)

"Departmental meetings are important. We do not only raise hands and count the number of those who agree and those who do not. Explanations are made and a consensus is sought." (Prof., PU)

In a similar manner, procedural justice also seems to be significant for a high quality LMX relationship in foundation universities. An academic who evaluated her relationship with her dean as very positive mentioned that she had the opportunity to express herself during periodic performance interviews.

"We have annual performance evaluations. We prepare reports of what we did and send it to the dean. The dean sends a letter of evaluation and holds an individual meeting with each of us. We talk together. I hear that this is not done in some other faculties. The goodwill of our dean is significant in such procedures." (Assist. Prof., FOU)

Hypothesis 3 suggested that interpersonal justice is an antecedent of LMX for academics in both types of university, but the regression analyses reveal that it is significant only in foundation universities. Therefore, Hypothesis 3 is partially accepted. In our interviews with faculty in public universities, interviewees mentioned that they had both bad and good times, just like families. One instructor said:

"Sometimes we have problems, but I prefer to forget about them and move on." (Inst., PU)

Because PhD students are often employed as full-time faculty after the completion of their $\mathrm{PhD}$ and continue their career path in the same university, they seem to believe that good and bad times will be balanced in the long run. Additionally, academics usually work with people who used to be their professors when they were students. For example, an academic said:

"The department head used to be a professor of mine. Our relationship is still similar to that of a student and professor." (Assist. Prof., PU)

Thus, because academics from public universities tend to see each other as members of the same family or as their professors rather than colleagues, they do not mind when the other party does not act kindly or respectfully on occasion.

Informational justice was expected to be an antecedent of LMX for academics in both public and foundation universities in Hypothesis 4 and this hypothesis is fully supported. As predicted, in shaping LMX perceptions of academics employed by public universities, informational justice had a significant influence. For example, an interviewee who perceived his supervisor as "not trustworthy in terms of information sharing" complained about lack of transparency:

"We only learned that somebody would be recruited to the department when the university announced publicly that there would be a new recruitment. We were not informed about it previously." (Assist. Prof., PU)

Information sharing is considered to be important in foundation universities as well. One academic declared:

"In the distribution of workload, we make lists of what we do and then it is shared with everybody. We know what others do. If I am given an extra task one day, my supervisor lets me know that others have done similar things on other days. He is a reasonable and fair person; I feel loyal to him." (Assist. Prof., FOU) 
On the other hand, a professor who said that she had almost no relationship with the department chair attributed her resentment to the lack of information sharing:

"She hides information and I feel like she uses it in line with her own interests. Maybe I am wrong, maybe she does not. But I do not know, so I feel resentful." (Prof., FOU)

\section{Discussion and Conclusion}

This study investigated the relative significance of organizational justice dimensions as antecedents of LMX in the context of academia, differentiating between foundation and public universities. In the past, organizational justice perceptions have been studied in primary and secondary schools in Turkey (e.g. Titrek, 2009; Yilmaz \& Tasdan, 2009), but the impact of justice perceptions in shaping LMX quality proved to be a fruitful area of study in the Turkish universities context as well. Results of the present investigation revealed that academics' LMX with their immediate supervisors is influenced to a large extent by their perceptions of organizational justice, particularly by informational and procedural justice dimensions. In line with the SET, justice emerges as a valuable contribution made by supervisors to their relationship with subordinates and increases the quality of LMX.

In public universities, informational justice and procedural justice emerge as the two determinants of LMX. In other words, academics do not target their supervisors in the face of distributive injustice and can more readily accept unequal treatment in the communication. However, they seek explanation (informational justice) and want to have their voices heard (procedural justice), regardless of the final decision. This may be due partly to the family-like atmosphere that seems to prevail in public universities. In such a context, academicians may believe that unequal distribution of rewards and disrespectful treatment will somehow even out in the long run. Recently, in a state university sample, Akbulut et al. (2015) showed that academics' perceptions of the leadership effectiveness of their department head was closely linked to the latter's collaborative leadership function. This function is based on intra-university interactions, and includes facilitator, mentor and empathizer roles. It can be suggested that the ability to fulfill these roles cannot be isolated from informational and procedural justice perceptions of subordinates, as shown by the results of the present study.

In public universities, academics seem to emphasize two-way communication with their immediate supervisors and the opportunity to participate in major decisions. This conclusion is in line with the literature. For example, Erdogan and Liden (2006) found that although interactional justice is a significant antecedent of LMX, it is less important for those employees who rate higher on collectivism. They assert that because collectivists view work relationships as family relationships and prioritize maintaining harmony, they do not retaliate in the face of interactional injustice. However, Erdogan and Liden (2006) did not study the sub-dimensions of interactional justice (interpersonal and informational justice) separately. Thus, the present findings contribute to the literature by proposing that the academics expect and value timely, comprehensive and truthful information to be given to them, but they may tolerate problems related to the nature of interpersonal communication.

In foundation universities, procedural, informational and interpersonal justice dimensions emerge as determinants of LMX. Academics at foundation universities have a tendency to attribute problems in their work contexts to the ways procedures are implemented by their supervisors; lack of institutionalization seems to be a problem for academicians in foundation universities. Most of the interviewees described their universities as either not institutionalized or flexible in the application of procedures. This is in line with the report of the Higher Education Council (YÖK, 2007). On the other hand, as expected, both sub-dimensions of interactional justice are antecedents of LMX in foundation universities. Therefore, academics at these universities not only value two-way communication with their supervisors, but they also emphasize respect and dignity in their work environment. This may also be result of a more short-term employment relationship, based on renewable contracts. Finally, contrary to the expectation put forward in this study, distributive justice does not have a substantial 
impact on LMX quality in foundation universities. As interviews revealed, boards of trustees rather than immediate supervisors are held responsible for the distribution of rewards in this context. Therefore, in line with Lavelle, Rupp and Brockner's (2007) suggestion, reactions in the face of distributive injustice are not targeted towards a party who is not held responsible for the action.

The present study has implications for supervisors in public and foundation universities. Enhancing procedural justice perceptions is important in building high-quality relationships with subordinates, regardless of whether procedures are institutionalized. In public universities, although rules and procedures are more established, how they are implemented may shape academics' perceptions of procedural justice. In foundation universities, on the other hand, due to lack of institutionalization, the perception of procedural justice becomes even more important in establishing high quality relationships. Supervisors should also pay attention to transparency and information sharing, as informational justice is another important determinant of LMX quality. Giving timely, objective, and accurate information improves a leader's relationship with subordinates. Additionally, supervisors in foundation universities should emphasize respect and politeness in their interpersonal relationships. Because employment relationships in foundation universities are not as long-term oriented as they are in public universities, consequences of occasional unjust behaviors in interpersonal relationships cannot be mended in the long run.

\section{Limitations and Future Research}

As in all research studies, the study has some limitations. First of all, the target population includes academics only from faculties of economics and administrative sciences in a single city. However, the research context hosts nearly one third of the universities in the country. This may limit problems with generalization. Future research may expand on this study by reaching various other faculties and universities in other cities.

In line with the aim of the study, this investigation includes dimensions of justice and a few control variables. As suggested in the recent literature (Colquitt et al., 2013), organizational justice is a potent determinant of LMX quality and the present model proved to be a parsimonious one, accounting for a significant variance of LMX quality. However, a number of other variables may be investigated as potential antecedents of LMX quality. There may also be variables that moderate or mediate the organizational justice-LMX relationship that could be investigated in future research.

\section{Acknowledgement}

This research project was supported by Bogazici University Research Fund with Grant Number 6365. All authors contributed equally to this work. 


\section{References}

Akbulut, M., Seggie, F., \& Börkan, B. (2015). Faculty member perceptions of department head leadership effectiveness at a state university in Turkey. International Journal of Leadership in Education, 18(4), 440-463.

Barblan, A., Erguder, U., \& Guruz, K. (2008). Higher education in Turkey: Institutional autonomy and responsibility in a modernising society. Bologna: Bononia University Press.

Bas, T., \& Ardic, K. (2002). A comparison of job satisfaction of public and private university academicians in Turkey. METU Journal of Development, 29(1), 27-46.

Bauer, T. N., \& Green, S. G. (1996). Development of leader-member exchange: A longitudinal test. Academy of Management Journal, 39(6), 1538-1567.

Beugre, C. D. (2002). Reacting aggressively to injustice at work: A cognitive stage model. Journal of Business and Psychology, 20(2), 291-301.

Biron, M., \& Boon C. (2013). Performance and turnover intentions: a social exchange perspective. Journal of Managerial Psychology, 28(5), 511-531.

Bolat, O. (2010). The relationships between leader-member exchange and organizational justice in hotels. European Journal of Economics, Finance and Administrative Sciences, (26), 1450-2275.

Brower, H. H., Schoorman, F. D., \& Tan, H. H. (2000). A model of relational leadership: The integration of trust and leader-member exchange. Leadership Quarterly, 11(2), 227-250.

Burton, J. P., Sablynski C. J., \& Sekiguchi, T. (2008). Linking justice, performance, and citizenship via leader-member exchange. Journal of Business Psychology, 23, 51-61.

Camerman, J., Cropanzano, R., \& Vandenberghe, C. (2007). The benefits of justice for temporary workers. Group and Organization Management, 32(2), 176-207.

Cetinsaya, G. (2014). Büyüme, Kalite, Uluslararasılaştırma: Türkiye Yükseköğretimi için Bir Yol Haritası [Growth, Quality, Internalization: A Roadmap for Higher Education in Turkey] (2nd ed.). Yükseköğretim Kurulu, Eskişehir, Turkey: Anadolu Üniversitesi Basımevi.

Chernyak-Hai, L., \& Tziner, A. (2014). Relationships between counterproductive work behavior, perceived justice and climate, occupational status, and leader-member exchange. Journal of Work and Organizational Psychology, 30, 1-12.

Cohen-Charash, Y., \& Spector, P. E. (2001). The role of justice in organizations: A meta-analysis. Organizational Behavior and Human Decision Processes, 86(2), 278-321.

Colquitt, J. A. (2001). On the dimensionality of organizational justice: A construct validation of a measure. Journal of Applied Psychology, 86(3), 386-400.

Colquitt, J. A., Rodell, J. B., Zapata, C. P., Scott, B. A., Long, D. M., Conlon, D. E., \& Wesson, M.J. (2013). Justice at the millennium, a decade later: A meta-analytic test of social exchange and affect-based perspectives. Journal of Applied Psychology, 98(2), 199-236.

Creswell, J., \& Plano-Clark, V. (2007). Designing and Conducting Mixed Method Research. Thousand Oaks, CA: Sage.

Cropanzano, R., Prehar, C. A., \& Chen, P. Y. (2002). Using social exchange theory to distinguish procedural from interactional justice. Group \& Organization Management, 27(3), 324-351.

Cropanzano, R., \& Mitchell, M. S. (2005). Social exchange theory: An interdisciplinary review. Journal of Management, 31(6), 874-900.

Cropanzano, R., Bowen, D. E., \& Gilliland, S. W. (2007). The management of organizational justice. Academy of Management Perspectives, 21(4), 34-48.

Cropanzano, R., \& Rupp, D. E. (2008). Social exchange theory and organizational justice: Job performance, citizenship behaviors, multiple foci and a historical integration of two literatures. In S. Gillilan, D. D. Steiner, \& D.P. Skarlicki (Eds.), Justice, Morality, and Social Responsibility (pp. 6399). Charlotte, NC: Information Age Publishing. 
De Boer, H., \& File, J. (2009). Higher Education Governance Reports across Europe. The Netherlands: Center for Higher Education Policy Studies.

Dill, D. D. (2003). Allowing the market to rule: The case of the United States. Higher Education Quarterly, 57(2), 136-157.

Dobbins, M., Knill C., \& Vögtle, E. (2011). An analytical framework for the cross-country comparison of higher education governance. Higher Education, 62(5), 665-683.

Erdem, A. R. ( 2012). Küreselleşme: Türk yükseköğretimine etkisi [Globalization: Effects on Turkish higher education]. Yükseköğretim Dergisi, 2(2), 109-117.

Erdogan, B., \& Liden, R. C. (2006). Collectivism as a moderator of responses to organizational justice: Implications for leader-member exchange and ingratiation. Journal of Organizational Behavior, 27, $1-17$.

Erdogan, B., Liden, R. C., \& Kramier, M. L. (2006). Justice and leader-member exchange: The moderating role of organizational culture. The Academy of Management Journal, 49(2), 395-406.

Ferreira, A. I., \& Hill, M. M. (2008). Organisational cultures in public and private Portuguese Universities: A case study. Higher Education, 55(6), 637-650.

Folger, R., \& Bies, R. J. (1989). Managerial responsibilities and procedural justice. Employee Responsibilities and Rights Journal, 2(2), 79-90.

Graen, G. B., \& Uhl-Bien, M. (1995). Relationship-based approach to leadership: Development of leader-member exchange (LMX) theory of leadership over 25 years: Applying a multi-level multi-domain perspective. Leadership Quarterly, 6(2), 219-247.

Gunay, D., \& Gunay, A. (2011). Quantitative developments in Turkish higher education since 1933. Journal of Higher Education and Science, 1(1), 1-22.

Iloh, C., \& Tierney W. (2014). Using ethnography to understand twenty-first century college life. Human Affairs, 24(2), 20-39.

Inelmen, K., Ozgumus, E., Parlak, G., Salti, N., \& Sariot, H. (2010). The effects of career commitment, organizational commitment and trust on organizational citizenship behaviors of hospital and hotel employees. International Journal of Business, Management and Economics, 11-12(4), 12-25.

Kutanis, R., \& Cetinel, E. (2009). Does the perception of injustice trigger cynicism? A case study. In 17th Management and Organization Proceedings (pp. 693-699). Eskişehir: Osmangazi University.

Lavelle, J., Rupp, D., \& Brockner, J. (2007). Taking a multifoci approach to the study of justice, social exchange, and citizenship behavior: The target similarity model. Journal of Management, 33(6), 841866.

Lee, P., Gillespie, N., Mann, L., \& Wearing, A. (2010). Leadership and trust: Their effect on knowledge sharing and team performance. Management Learning, 41(4), 473-491.

Liden, R. C., Sparrowe, R. T., \& Wayne, S. J. (1997). Leader-member exchange theory: The past and potential for the future. Research in Personnel and Human Resource Management, 15, 47-119.

Loi, R., Yang, J., \& Diefendorff, J. (2009). Four-factor justice and daily job satisfaction: A multilevel investigation. Journal of Applied Psychology, 2009(94), 770-781.

Masterson, S. S., Lewis, K., Goldman, B. M., \& Taylor, M. S. (2000). Integrating justice and social exchange: the differing effects of fair procedures and treatment on work relationships. Academy of Management Journal, 43(4), 738-748.

Masterson S. S., \& Lensges, M. (2015). Leader-Member exchange and justice. In T.N. Bauer, \& B. Erdogan (Eds.), The Oxford Handbook of Leader-Member Exchange. Oxford: Oxford University Press.

Mathooko, F. M., \& Ogutu, M. (2015). Porter's five competitive forces framework and other factors that influence the choice of response strategies adopted by public universities in Kenya. International Journal of Educational Management, 29(3), 334-354. 
Minibas-Poussard, J., \& Erkmen, T. (2008). Yönetim, iletişim, kültür [Management, communication, culture] (1sted.). Istanbul: Arıkan Yayınevi.

Mizikaci, F. (2006). Higher Education in Turkey. Bucharest: UNESCO-CEPES.

Munaf, S. (2009). Motivation, performance and satisfaction among university teachers: Comparing public and private sectors in Pakistan and Malaysia. South Asian Journal of Management, 16(4), 728.

Sam, C., \& van der Sijde, P. C. (2014). Understanding the concept of the entrepreneurial university from the perspective of higher education models. Higher Education, 68, 891-908.

Tekleab, A. G., Takeuchi, R., \& Taylor, M. S. (2005). Extending the chain of relationships among organizational justice, social exchange, and employee reactions: The role of contract violations. Academy of Management Journal, 48(1), 146-157.

Tekleab, A., \& Taylor, M. (2003). Aren't there two parties in an employment relationship? Antecedents and consequences of organization-employee agreement on contract obligations and violations. Journal of Organizational Behavior, 24(5), 585-608.

Titrek, O. (2009). Employees' organizational justice perceptions in Turkish schools. Social Behavior and Personality, 37(5), 605-620.

Usdiken, B. (2004). The French, the German and the American: Higher education for business in Turkey. New Perspectives on Turkey, 31, 5-38.

Walumbwa, F. O., Cropanzano, R., \& Hartnell, C. A. (2009). Organizational justice, voluntary learning behavior, and job performance: A test of the mediating effects of identification and leadermember exchange. Journal of Organizational Behavior, 30, 1103-1126.

Yilmaz, K., \& Tasdan M. (2009). Organizational citizenship and organizational justice in Turkish primary schools. Journal of Educational Administration, 47(1), 108-126.

YÖK. (2007). Vakıf Üniversiteleri Raporu [Foundation Universities Report]. Ankara. 


\section{Appendix 1. Questionnaire of the Study (in Turkish)}

1. Doğum yılınız:

2. Cinsiyetiniz: ( ) Kadın ( ) Erkek

3. Eğitiminiz: ( ) Yüksek Lisans Mezuniyet yılınız:
( ) Doktora
Mezuniyet yılınız:

4. Doktora yaptığınız veya yapmakta olduğunuz alan:

5. Akademik ünvanınız

6. Çalıştığınız üniversite ( ) kamu üniversitesi ( ) vakıf üniversitesi

7. Kaç yıldır bu üniversitede çalışıyorsunuz?

8. Hangi fakültede çalışıyorsunuz?

9. İdari göreviniz var ise belirtiniz (ör. Kürsü/bölüm başkanı, dekan veya yardımcısı)

10. Aylık net gelirinizi belirtiniz.
( ) 1500-2500
( ) 2501-3500
( ) 35014500
( ) 4501-5500
( ) $5501-\ldots$

I. Aşağıdaki ifadeleri şu anda akademik çalışma ortamınızda bağlı olduğunuz yöneticiyi düşünerek yanıtlayınız. Lütfen aşağıda verilen ölçeği kullanarak her bir ifadeye ne derece katıldığınızı belirtiniz.

\begin{tabular}{|c|c|c|c|c|}
\hline $\begin{array}{c}\text { Kesinlikle } \\
\text { katılmıyorum }\end{array}$ & Katılmiyorum & $\begin{array}{l}\text { Ne katıliyorum } \\
\text { ne katılmiyorum }\end{array}$ & Katıliyorum & $\begin{array}{c}\text { Kesinlikle } \\
\text { katılıyorum }\end{array}$ \\
\hline
\end{tabular}

Yöneticimin yaptığım işten ne

1. kadar memnun olduğunu her

1

3

4

5

zaman bilirim.

Yöneticim sorunlarımı ve

2. ihtiyaçlarımı yeterince iyi

1

2

3

4

5

anlar.

3. Yöneticim potansiyelimin

yeterince farkında değil.

12

3

4

5

Yöneticim benim iş yerindeki

4. sorunlarımı çözmek için kendi

1

2

3

4

5

gücünü kullanır.

Yöneticime gerçekten ihtiyacım

5. olduğunda kendi zararına dahi

olsa beni kurtaracağ 1

1

2

3

4

5

konusunda güvenirim.

Yöneticime kendisinin

6. bulunmadığı ortamlarda

kararlarını savunacak kadar

1

2

3

4

5

güvenirim.

Yöneticimle olan iş ilişkim son

7. derece uyumlu ve verimlidir.

1

2

3

4

5 
II. Aşağıdaki ifadeler iş yerinde elde ettiğiniz sonuçlarla (bu sonuçlar maddi veya sosyal olabilir) ilgilidir. Lütfen aşağıda verilen ölçeği kullanarak her bir ifadeye ne derece katıldığınızı belirtiniz.

1. İş yerinde elde ettiğiniz sonuçlar

1. gösterdiğiniz çabayı yansıtır $\mathrm{m}$ ? Çok $\mathrm{Az} \quad \mathrm{Az} \quad$ Kısmen Yeterince Büyük Ölçüde

Elde ettiğiniz sonuçlar ile tamamladığınız

2. işler birbiriyle uyumlu mudur?

$\begin{array}{lllll}1 & 2 & 3 & 4 & 5\end{array}$

Elde ettiğiniz sonuçlar işyerine yaptığınız

3. katkılarla doğru orantılı mıdır?

$\begin{array}{llllll}1 & 2 & 3 & 4 & 5\end{array}$

Performansınız göz önüne alındığında elde

4. ettiğiniz sonuçlar makul müdür?

$\begin{array}{llllll}1 & 2 & 3 & 4 & 5\end{array}$

$\begin{array}{llllll}1 & 2 & 3 & 4 & 5\end{array}$

III. Aşağıdaki ifadeler iş ortamında karşılaştığınız atama, yükseltme, görevlendirme, ücretlendirme gibi süreçler ile ilgilidir. Lütfen aşağıda verilen ölçeği kullanarak her bir ifadeye ne derece katıldığınızı belirtiniz.

\begin{tabular}{|c|c|c|c|c|c|}
\hline & Çok Az & $\mathrm{Az}$ & Kismen & Yeterince & $\begin{array}{l}\text { Büyük } \\
\text { Ölçüde }\end{array}$ \\
\hline $\begin{array}{l}\text { Bakış açınızı ve duygularınızı bu süreçler } \\
\text { esnasında ifade edebiliyor musunuz? }\end{array}$ & 1 & 2 & 3 & 4 & 5 \\
\hline $\begin{array}{l}\text { Bu süreçler neticesinde elde edilen sonuçlar } \\
\text { ü. üzerinde etkiniz var mıdır? }\end{array}$ & 1 & 2 & 3 & 4 & 5 \\
\hline $\begin{array}{l}\text { 3. Bu süreçler tutarlı bir şekilde uygulanıyor } \\
\mathrm{mu} \text { ? }\end{array}$ & 1 & 2 & 3 & 4 & 5 \\
\hline $\begin{array}{l}\text { Bu süreçler önyargılardan uzak uygulaniyor } \\
\text { mu? }\end{array}$ & 1 & 2 & 3 & 4 & 5 \\
\hline $\begin{array}{l}\text { 5u süreçler doğru ve tutarlı bilgilere mi } \\
\text { dayandırılmıştır? }\end{array}$ & 1 & 2 & 3 & 4 & 5 \\
\hline $\begin{array}{l}\text { Süreçler neticesinde sonuçların düzeltilmesini } \\
\text { talep edebilir misiniz? }\end{array}$ & 1 & 2 & 3 & 4 & 5 \\
\hline $\begin{array}{l}\text { 7. Bu süreçler etik ve ahlaki standartlara uygun } \\
\text { mudur? }\end{array}$ & 1 & 2 & 3 & 4 & 5 \\
\hline
\end{tabular}

IV. Aşağıdaki ifadeleri şu anda akademik çalışma ortamınızda bağlı olduğunuz yöneticiyi düşünerek yanıtlayınız. Lütfen aşağıda verilen ölçeği kullanarak her bir ifadeye ne derece katıldığınızı belirtiniz.

\begin{tabular}{lccccc}
\hline & Çok Az & $\mathrm{Az}$ & Kismen & Yeterince & $\begin{array}{c}\text { Büyük } \\
\text { Ölçüde }\end{array}$ \\
\hline 1. Size nazik davranır mı? & 1 & 2 & 3 & 4 & 5 \\
\hline 2. Size itibar gösterir mi? & 1 & 2 & 3 & 4 & 5 \\
\hline 3. Size saygılı davranır mı? & 1 & 2 & 3 & 4 & 5 \\
\hline $\begin{array}{l}\text { Size karşı uygunsuz yorum ve eleştirilerden } \\
\text { kaçınır mı? }\end{array}$ & 1 & 2 & 3 & 4 & 5 \\
\hline 5. Sizinle olan iletişimininde samimi midir? & 1 & 2 & 3 & 4 & 5 \\
\hline 6. Süreçleri bütünüyle açıllar mı? & 1 & 2 & 3 & 4 & 5 \\
\hline 7. Süreçlere yönelik açılamaları mantıklı mıdır? & 1 & 2 & 3 & 4 & 5 \\
\hline 8. Süreçlere yönelik ayrıntıları zamanında aktarır mı? & 1 & 2 & 3 & 4 & 5 \\
\hline $\begin{array}{l}\text { 9. Iletişim kurarken bireylerin bilişsel ihtiyaçlarına } \\
\text { göre uyarlama yapar mı? }\end{array}$ & 1 & 2 & 3 & 4 & 5 \\
\hline
\end{tabular}

